\title{
SOSIALISASI TATA KELOLA PENANGANAN COVID DAN TINDAKAN PREVENTIF DI ERA NEW NORMAL
}

\author{
M. Fajar Anugerah, Muhammad Arif, Syed Agung Afandi, Reski Lestari \\ Universitas Abdurrab, Indonesia \\ fajar.anugerah@univrab.ac.id
}

\begin{abstract}
The spread of the Corona Desease 2019 (Covid-19) Virus in Indonesia is currently increasingly widespread because many people have not realized and implemented the rules set by the government in the midst of a new normal life. The method of implementation in this community service activity is the socialization method of visiting residents from house to house by providing a brief understanding of the governance of Covid-19 management and preventive measures in the new normal era and ending with the distribution of masks, brochures and stickers. This is to know that public awareness and awareness about the importance of alarms and prevention in today's new era of normal life. This type of research is qualitative research that understands the phenomena of what the research subject is doing, such as behavior, perception, motivation in the form of words and language, in a special natural context and by utilizing various natural methods. The research sample was the community from the umbrella sub-district sekaki, Tirta District, Pekanbaru. The results showed that when conducting socialization, the community was very enthusiastic about this activity, they heard and understood well from the socialization we provided. when we put on the masks that were given for free they followed our directions properly. They were very enthusiastic about reading our brochures because we designed brochures with bright themes and did not read to become bored while reading. and also we give and stick stickers in places of worship or other places of association so that you remember to keep a minimum distance of $1 \mathrm{~m}$ to protect yourself.
\end{abstract}

Keywords: Governance, Preventive Action, Covid-19.

\begin{abstract}
Abstrak
Penyebaran Corona Virus Desease 2019 (Covid-19) di Indonesia saat ini sudah semakin meluas karena banyak nya masyarakat yang belum menyadari dan menerapkan aturan yang di tetapkan pemerintah di tengah berlakunya new normal life. Metode Pelaksanaan dalam kegiatan pengabdian kepada masyarakat ini adalah dengan metode sosialisasi mengunjungi warga dari rumah ke rumah dengan memberikan pemahaman singkat tentang tata kelola penanganan covid19 dan tindakan preventif di era new normal dan di akhiri dengan pembagian masker, brosur dan stiker., Tujuan penelitian ini adalah untuk mengetahui pengetahuan dan kesadaran masyarakat tentang pentingnya mengetahui gejala dan pencegahan di era new normal life saat ini. Jenis penilitian ini adalah kualitatif penelitian yang bermaksud memahami fenomena tentang apa yang dialami oleh subjek penelitian misalnya perilaku, persepsi, motivasi dalam bentuk kata-kata dan bahasa, pada suatu konteks khusus yang alamiah dan dengan memanfaatkan berbagai metode alamiah. Sampel penelitian ialah masyarakat dari kecamatan payung sekaki kelurahan Tirta Pekanbaru. Hasil penelitian menunjukkan bahwa saat melakukan sosialisasi masyarakat sangat antusias dalam kegiatan ini, mereka mendengar dan memahami dengan baik dari sosialisasi yang kami berikan. saat kami mengatakan memakai masker yang diberikan secara gratis mereka mengikuti arahan dari kami dengan baik dan benar. Mereka sangat antusias membaca brosur dari kami karna kami mendesain brosur dengan tema terang dan tidak menjadikan pembaca menjadi bosan saat membaca. dan juga kami memberikan dan menempel stiker di kawasan ibadah atau tempat perkumpulan lainnya agar tetap ingat jaga jarak min $1 \mathrm{~m}$ untuk melindungi diri.
\end{abstract}

Kata Kunci: Tata Kelola, Tindakan Preventif, Covid-19. 


\section{Pendahuluan}

Saat ini Wabah Coronavirus Disease (Covid-19) menjadi Isu kesehatan yang paling menghebohkan seluruh dunia, termasuk Indonesia. Penanggulangan ekstrem seperti Lockdown suatu daerah bahkan suatu negara pun dilakukan sebagai upaya untuk meminimalisir penyebaran penyakit tersebut. Untuk mendukung keberhasilan lockdown suatu daerah harus diikuti dengan upaya tata kelola penanganan agar upaya preventif dapat berjalan sesuai dengan yang diharapkan, menurut Ramalingam (dalam Wilson \& Jumbert, 2018) bahwa dalam tata kelola penanganan mengatasi wabah yang berskala internasional setidaknya dibutuhkan lima pihak terkait yaitu antar instansi pemerintah, instasi pemerintah tingkat nasional, yayasan swasta, mitra pemerintah dari swasta/publik dan konsorsium. Berbagai protokol baik dalam skala internasional, nasional, lokal, maupun wilayah kecil seperti desa/kelurahan harus mengikuti aturan yang ada. Berbagai kesepakatan ataupun aturan telah banyak ditetapkan, namun ternyata tidak mudah dalam menangani kasus pandemi ini, karena masih terbatas pada kebijakan yang sifatnya umum. Untuk itu diperlukan koordinasi yang lebih terarah dalam implementasi di masyarakat. Hal ini dilakukan karena Indonesia merupakan negara yang multi kultural dengan berbagai keragaman, sehingga diperlukan pengelolaan bersama antar berbagai lembaga (Sunuantari \& Zarkasi, 2020)

Belakangan ternyata ditemukan bahwa diameter virus corona diperkirakan mencapai 125 nanometer atau 0,125 mikrometer. Satu mikrometer sama dengan 1000 nanometer. Kecil sekali dan tak mungkin pandangan telanjang manusia mampu melihatnya. Sekalipun sangat kecil dan manusia yang tak mau berpikir meremehkannya, virus ini mampu bertahan lebih dari 10 menit di permukaan, termasuk tangan. Bahkan WHO menyebut virus corona baru (Covid-19) dapat bertahan selama beberapa jam, bahkan beberapa hari dan dapat bertahan hidup di suhu 26-27 derajat celcius (Zahrotunnimah, 2020). Pada sebagian besar kasus, corona virus hanya menyebabkan infeksi pernapasan ringan sampai sedang, seperti flu. Akan tetapi, virus ini juga bisa menyebabkan infeksi pernapasan berat, seperti pneumonia, Middle-East Respiratory Syndrome (MERS), dan Severe Acute Respiratory Syndrome (SARS). Virus ini termasuk penyakit menular dan baru ditemukan di Wuhan, China pada Desember 2019 yang kemudian menjadi wabah. Ada dugaan bahwa virus Corona awalnya ditularkan dari hewan ke manusia. Namun, kemudian diketahui bahwa virus Corona juga menular dari manusia ke manusia (Nurhalimah, 2020).

Gejala awal infeksi COVID-19 bisa menyerupai gejala flu, yaitu demam, pilek, batuk kering, sakit tenggorokan, dan sakit kepala. Setelah itu, gejala dapat hilang dan sembuh atau malah memberat. Penderita dengan gejala yang berat bisa mengalami demam tinggi, batuk berdahak atau berdarah, sesak napas, dan nyeri dada. Gejala-gejala tersebut di atas muncul ketika tubuh bereaksi melawan virus COVID-19. Gejala COVID-19 bisa muncul dalam 2 hari sampai 2 minggu setelah seseorang terinfeksi virus penyebabnya (Pane, 2020). Di tengah adaptasi new normal saat ini masyarakat sangat di anjurkan untuk cuci tangan dengan teratur, atur pernafasan, gunakan hand sanitizer, stay at home, jaga jarak, gunakan masker, hindari menyentuh wajah. New normal menurut aturan atau menurut pola yang umum, sesuai dan tidak menyimpan dari suatu norma atau kaidah, sesuai dengan keadaan yang biasa, tanpa cacat, tidak ada kelainan 
sedangkan Era New Normal zaman normal baru atau bersifat normaldengan sesuatu yang baru, hal ini merupakan anggapan yang bersama-sama mewujudkan keadaan normal kembali seperti biasanya dengan berbagai persyaratan yang ditentukan dengan protokoler kesehatan demi keselamatan semua orang (Mustakim, 2020). sesuatu yang biasa dengan suasana yang baru dengan perlakuan yang baru seperti definisi new normal menurut Pemerintah Indonesia adalah tatanan baru untuk beradaptasi dengan COVID-19. Lebih lanjut Achmad Yurianto mengatakan, masyarakat harus menjaga produktivitas di tengah pandemi virus corona COVID-19 dengan tatanan baru yang disebut new normal.

Permasalahan perilaku kesehatan pada masyarakat ialah kurangnya kesadaran untuk memakai masker, jaga jarak, malas mencuci tangan serta tidak memakai hand sanitizer dan perilaku sederhana berdampak luar biasa. Permasalahan perilaku kesehatan pada masyarakat ialah kurangnya kesadaran untuk memakai masker, jaga jarak, malas mencuci tangan serta tidak memakai hand sanitizer. Perilaku sederhana berdampak luar biasa (Peraturan Menteri Kesehatan Republik Indonesia Nomor 3 Tahun 2014 Tentang Sanitasi Total Berbasis Masyarakat, 2014). Pemerintah melalui Kementerian Kesehatan tak henti-hentinya melakukan sosialisasi dan edukasi kepada masyarakat agar memahami protokol kesehatan yang harus dilakukan dimanapun kita berada terutama di lingkungan sekitar. Tatanan kehidupan baru, bisa dilakukan setelah adanya indikasi penurunan kurva penyebaran angka Covid-19 menurun. Tersedianya fasilitas kesehatan yang mumpuni dan pengawasan yang ketat. Inilah yang menjadi tanggung jawab kita bersama dalam menghadapi new normal di tengah pandemi Covid-19.

Gejala-gejala covid 19 yang paling umum adalah Demam, batuk kering dan lelah. Gerjala lainnya yang lebih jarang atau mungkin dialami beberapa pasien meliputi rasa nyeri dan sakit, hidung tersumbat, sakit kepala, kongjungtivitis, sakit tenggorokan, diare, kehilangan indra rasa atau penciuman, ruam pada kulit, atau perubahan warna jari tangan atau kaki. Gejala-gejala yang dialami biasanya bersifat ringan dan muncul secara bertahap. Berberapa orang menjadi terinfeksi tetapi hanya memiliki gejala ringan. Cara melindungi diri dan mencegah covid menurut WHO:

1. Sering mencuci tangan anda dengan air bersih mengalir dan sabun, atau cairan antiseptik berbahab dasar alkohol.

2. Jaga jarak setidaknya 1 meter dengan orang lain.

3. Hindari pergi ketempat-tempat ramai.

4. Hindari menyentuh mata, hidung, dan mulut.

5. Pastikan anda dan orang sekitar menjalankan etika batuk dengan cara menutup mulut dan hidung dengan siku terlipat atau tisu untuk batuk dan bersin.

6. Tetaplah tingggal dirumah dan lakukan isolasi mandiri meskipun memiliki gejala ringan.

7. Jika anda demam, batuuk dan sesak nafar segera minta pertolongan medisdan tetap memberitahu kondisi anda sebelumnya.

8. Tetap ikuti informasi terbaru dari sumber terpercaya seperti WHO, Dinas Kesehatan daerah dan kementrian kesehatan daerah.

Masyarakat yang kurang peduli dengan cara pencegahan dari covid 19 sangat rentan terkena penyakit ini, selain rentan dalam kesehatan masyarakat yang kurang peduli terhadap perilaku hidup bersih dan sehat dengan adanya covid ini sangat rentan 
juga terjadinya penularan sehingga ini akan menjadi masalah besar di kemudian hari (Anugerah et al., 2019). Masyarakat dari jalan sekolah RT/RW 02/03 Kelurahan Tirta Siak, Kecamatan Payung Sekaki, Kota Pekanbaru merupakan daerah yang berada di sisi kota. Dari wawancara yang kami lakukan dengan mitra Ibu Elvanelin salah satu ketua dari Ibu Kreativ di daerah tersebut mengatakan masih adanya masyarakat yang kurang peduli dengan kebiasaan di era new normal saat ini. Alat yang dibutuhkan dalam sosialisasi ini adalah brosur yang berisikan tata kelola penangan dan upaya preventif di era new normal, stiker dan masker. Sehingga kami tertarik melakukan sosialisasi tata kelola penanganan covid dan tindakan preventif di era new normal dengan tujuan untuk meningkatkan kewaspadaan masyarakat terhadap wabah ini serta mumutus mata rantai covid-19 yang semakin meningkat di Kota Pekanbaru.

\section{Metode}

Metode Pelaksanaan dalam kegiatan pengabdian kepada masyarakat ini adalah dengan metode sosialisasi mengunjungi warga dari rumah ke rumah dengan memberikan pemahaman singkat tentang tata kelola penanganan covid-19 dan tindakan preventif di era new normal dan di akhiri dengan pembagian masker, brosur dan stiker. Pengabdian dilakukan di jalan sekolah RT/RW 02/03 Kelurahan Tirta Siak, Kecamatan Payung Sekaki, Kota Pekanbaru. Metode yang digunakan dalam kegiatan pengabdian kepada masyarakat ini adalah dengan melakukan observasi ke rumah-rumah warga untuk melihat sejauh mana pentingnya mengetahui gejala dan pencegahaan covid karena memang belum ada kegiatan serupa di lokasi pengabdian ini. Partisipasi mitra dalam kegiatan pengabdian kepada masyarakat ini yaitu warga dari RT/RW 02/03 Kelurahan Tirta Siak, Kecamatan Payung sekaki kota pekanbaru bersama Mahasiswa Kukerta Universitas Abdurrab Pekanbaru. Evaluasi pelaksanaan kegiatan pengabdian kepada masyarakat ini dilakukan dengan memberikan pengarahan tentang hidup sehat yang dimulai dari mengenali gejala dan pencegahan dari covid. Keberhasilan kegiatan pengabdian ini diukur dari antusias masyarakat dan adanya respon positif dari ketua RT/RW setempat. Di Akhir Sosialisasi mahasiswa mempraktekan kegiatan menggunakan masker dengan benar kepada masyarakat.

\section{Hasil dan Pembahasan}

Dalam undang-undang nomor 23 tahun 1992 tentang kesehatan ditetapkan bahwa kesehatan adalah keadaan sejahtera dari badan, jiwa dan sosial yang memungkinkan setiap orang hidup produktif secara sosial dan ekonomi. Dari kegiatan yang kami lakukan kamu memilih untuk mensosialisasikan cara menegtahui gejala dan pencegahan covid yang baik dan benar. bagi masyarakat yang belum mengetahui cara tersebut karna sangat bermanfaat untuk kesehatan diri sendiri dan orang lain. Kegiatan sosialisasi ini merupakan salah satu kegiatan program kerja nyata kelompok 28 di kelurahan tirta Siak, kecamatan Payung sekaki. Kegiatan ini dilaksanakan di rumah-rumah warga dari Rt/Rw 02/03 Kelurahan Tirta Siak, Kecamatan Payung sekaki. Subjek dari kegiatan yaitu masyarakat daerah tersebut yang berjumlah 30 orang. Saat melakukan sosialisasi masyarakat sangat antusias dalam kegiatan ini, mereka mendengar dan memahami dengan baik dari sosialisasi yang kami berikan. saat kami mengatakan memakai masker yang diberikan secara gratis mereka mengikuti arahan dari kami dengan baik dan benar. 
Mereka sangat antusias membaca brosur dari kami karna kami mendesain brosur dengan tema terang dan tidak menjadikan pembaca menjadi bosan saat membaca. dan juga kami memberikan dan menempel stiker di kawasan ibadah atau tempat perkumpulan lainnya agar tetap ingat jaga jarak min $1 \mathrm{~m}$ untuk melindungi diri. mereka sangat menyukai dan dapat mengikuti sosialisasi ini dengan baik dan kami harapkan bisa menerapkannya dalam kehidupan sehari-hari agar menjauhkan dan menghindari diri mereka untuk terserang penyakit.

Dibawah ini terdapat dokumentasi saat kami kelompok 28 melaksanakan kegiatan sosialisasi yang dilakukakan pada masyarakat di Jalan Sekolah RT/RW 02/03 Kelurahan Tirta Siak, Kecamatan Payung Sekaki, Kota Pekanbaru.

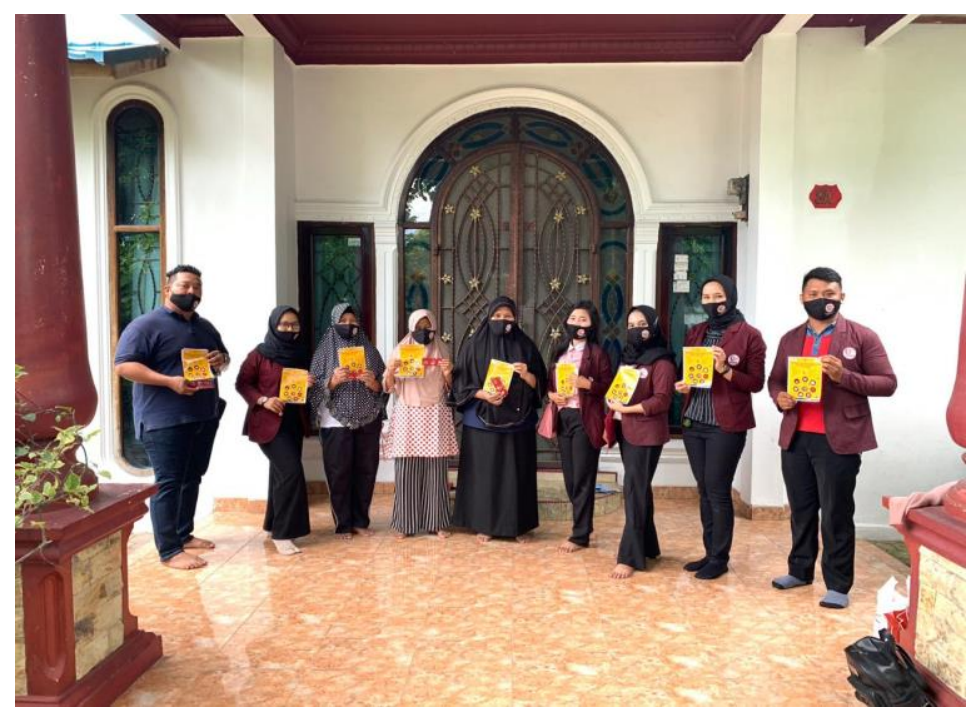

Gambar 1. Foto bersama dengan ketua Rt/Rw 02/03 dan mitra dari ibu-ibu kreatif

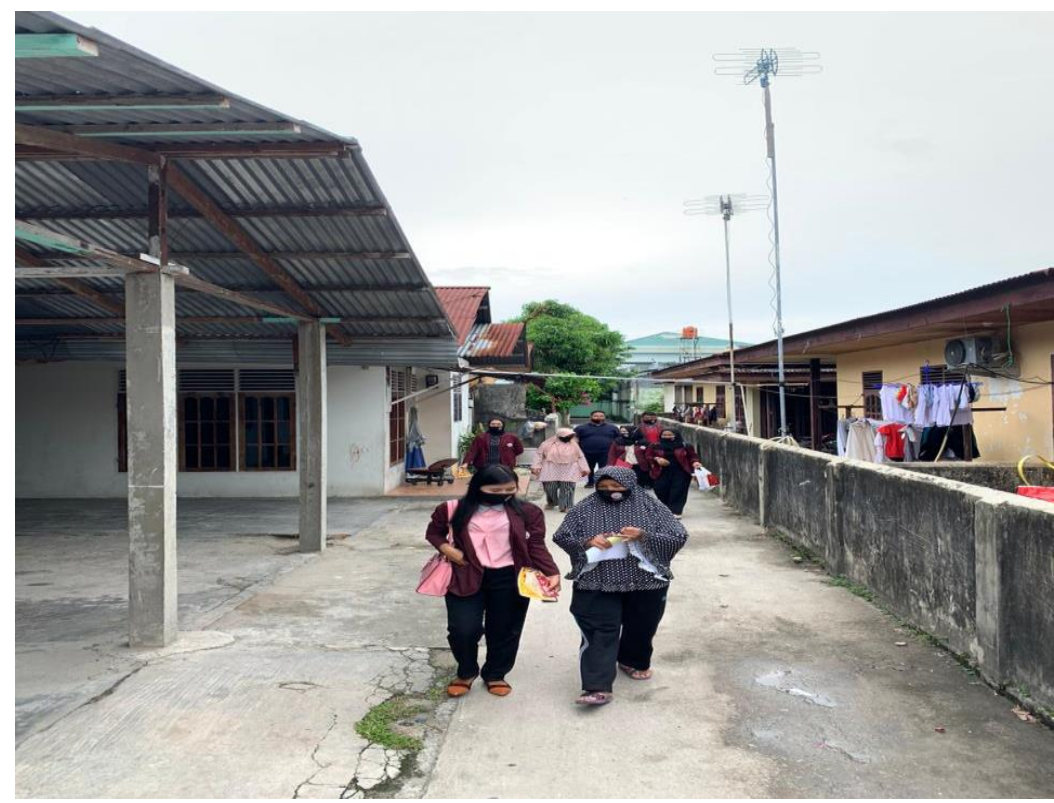

Gambar 2. Sosialiasi door to door yang di arahkan dan di temani oleh Ibu RT/RW 


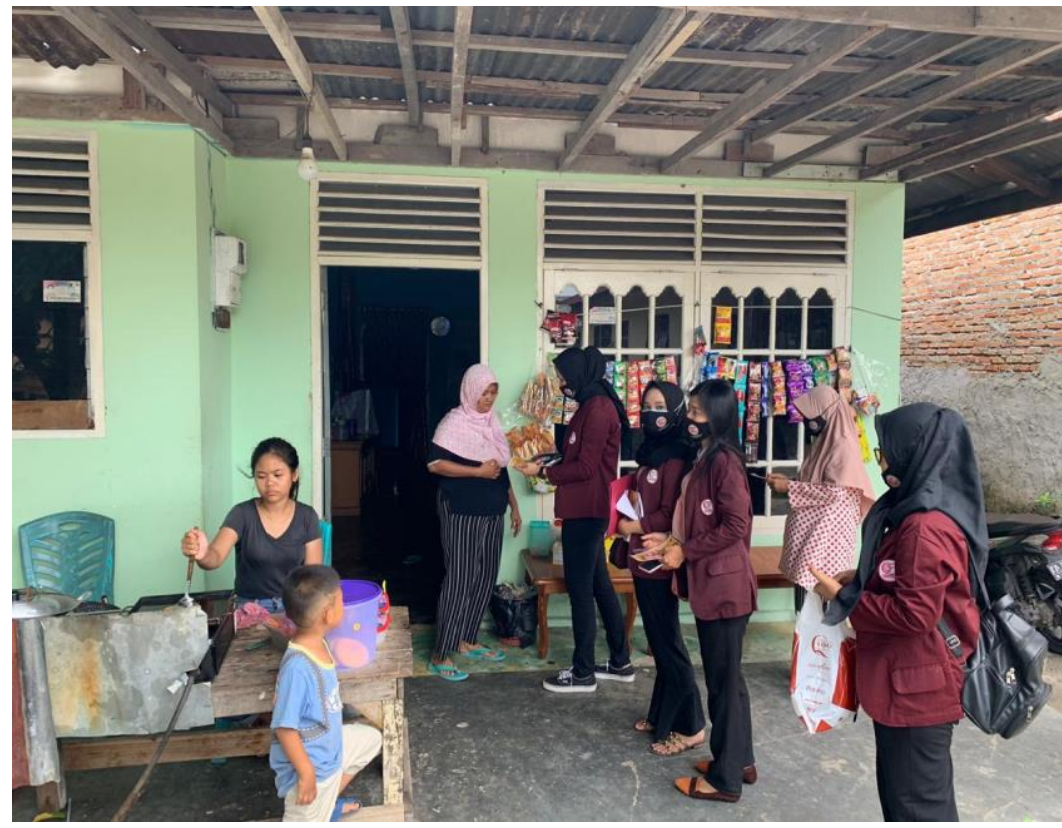

Gambar 3. Sosialisasi Tata kelola Penanganan Covid dan Tindakan Preventiv di Era New Normal serta pembagian brosur mengenali gejala dan pencegahan covid, stiker jaga jarak dan Masker kepada masyarakat setempat.

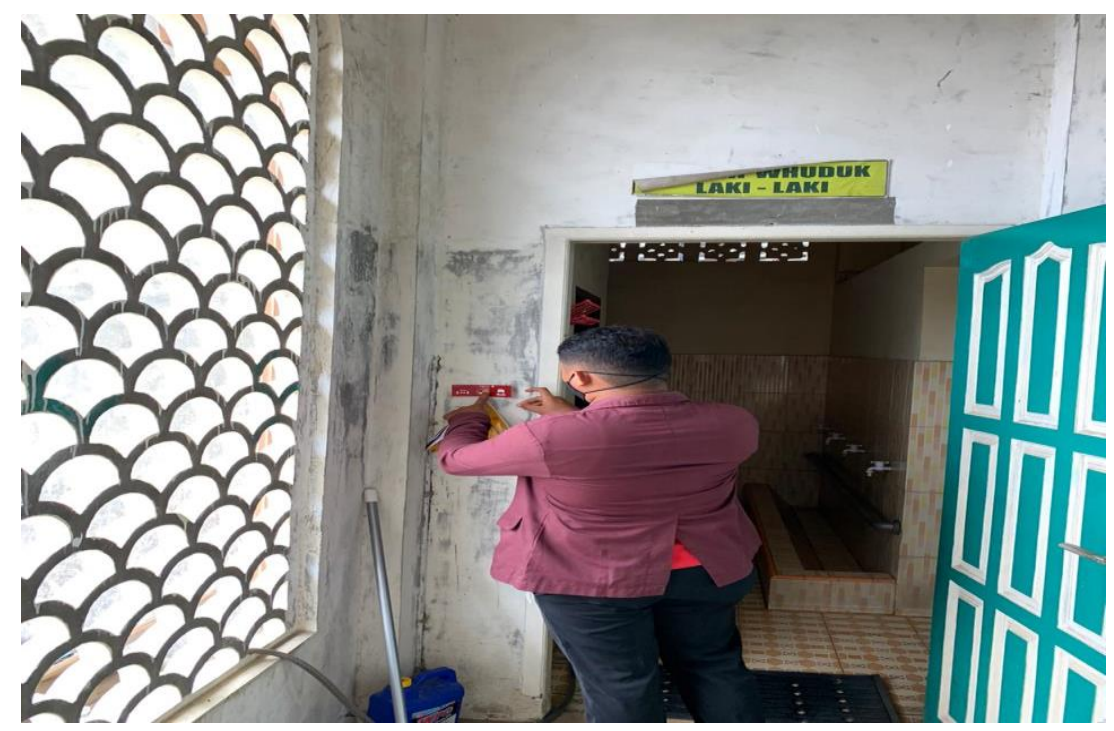

Gambar 4. Menempel Stiker tetap jaga jarak di Area ibadah dan tempat umum. 


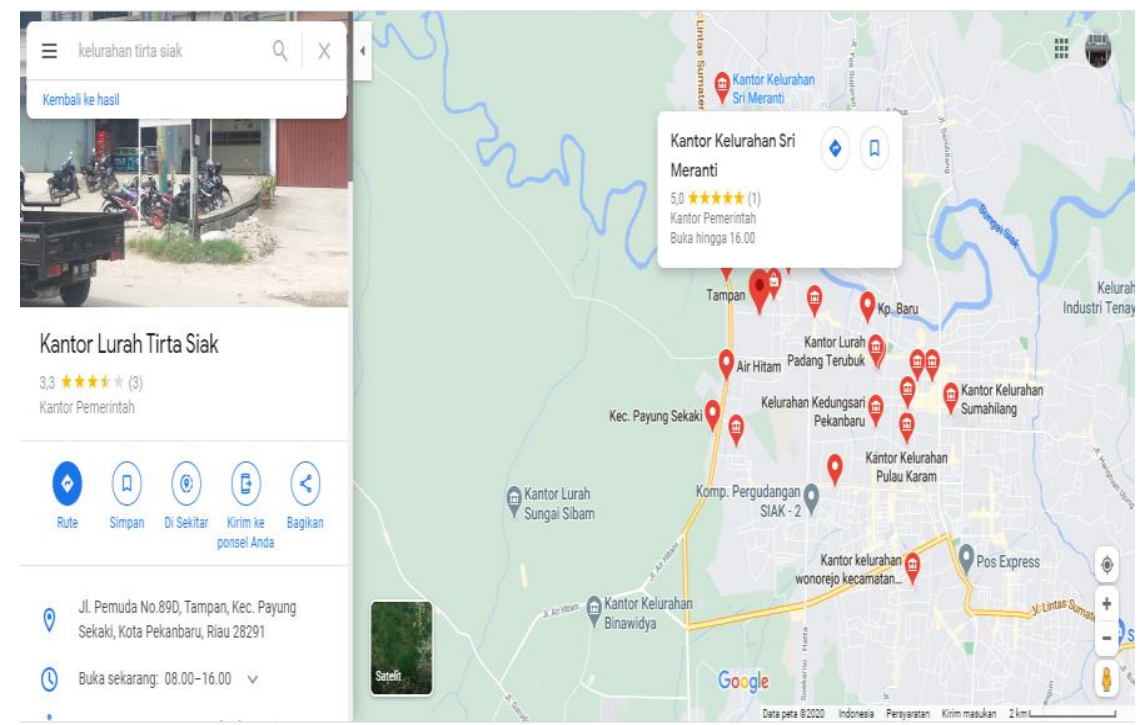

Gambar 5. Lokasi Kegiatan

\section{Kesimpulan}

Secara Keseluruhan kegiatan Sosialisasi yang di berikan mahasiswa Kukerta Univrab kelompok 28 kepada Masyarakat Rt/Rw 02/03 kelurahan tirta Siak Kecamatan Payung Sekaki berjalan lancar. Jika ada kegiatan Sosialisasi lagi bisa dilakukan dengan lebih baik lagi dan terarah dan mempersiapkan segala bentuk dari sosialisasi penangan covid ini sangat bermanfaat bagi kesehatan dan diharapkan dengan adanya kegiatan seperti ini di harapkan agar masyarakat menyadari betapa penting mencegah dari pada mengobati. Terimakasih kepada Bapak M Fajar Anugrah S.IP., M.Si selaku Dosen pembimbing lapangan, kepada mitraIibu Elvanelin yang telah menjadi jembatan dalam sosialisai dari kukerta univrab kelompok 28 sehingga sosialisasi ini berjalan dengan lancar, kepada Masyarakat RT/RW 02/03 Kelurahan Tirta Siak Kecamatan Payung Sekaki yang telah mengizinkan kami dan mendukung kami dalam kegiatan Sosialisasi sehingga kegiatan ini berjalan dengan baik.

\section{Daftar Pustaka}

Anugerah, M. F., Yulianti, W., \& Juariah, S. (2019). Penyuluhan Cuci Tangan Pakai Sabun Di Sdn 128 Pekanbaru Kelurahan Rantau Panjang Pekanbaru. Jurnal Pengabdian Masyarakat Multidisiplin, 3(3), 181-186.

Peraturan Menteri Kesehatan Republik Indonesia Nomor 3 Tahun 2014 tentang Sanitasi Total Berbasis Masyarakat, Implementation Science (2014). https://doi.org/10.4324/9781315853178

Mustakim, U. S. (2020). Uniqbu Journal Of Exact Sciences ( UJES ). Efektivitas Pembelajaran Di Era New Normal Terhadap Hasil Belajar Mahasiswa Pada Mata Kuliah Matematika Diskrit (Effectiveness, 1(April), 41-45.

Nurhalimah, N. (2020). Upaya Bela Negara Melalui Sosial Distancing Dan Lockdown Untuk Mengatasi Wabah Covid-19 (Efforts to Defend the Country Through Social Distancing and Lockdown to Overcome the COVID-19 Plague). Available at SSRN 3576405.

Pane, M. D. C. (2020). Virus Corona (COVID-19) - Gejala, penyebab dan mengobati - 
Alodokter. Aladokter.

Sunuantari, M., \& Zarkasi, I. R. (2020). Tata kelola black zone covid-19 berbasis komunitas.

Zahrotunnimah, Z. (2020). Langkah Taktis Pemerintah Daerah Dalam Pencegahan Penyebaran Virus Corona Covid-19 di Indonesia. SALAM: Jurnal Sosial Dan Budaya Syar-I. https://doi.org/10.15408/sjsbs.v7i3.15103 